Наносистели, нанолатеріали, нанотехнології Nanosistemi, Nanomateriali, Nanotehnologii 2019 , т. 17 , № 3, сc. 465-472 (c) 2019 ІМФ (Інститут металофізики ім. Г. В. Курдюмова НАН України) Надруковано в Україні. Фотокопіювання дозволено тільки відповідно до ліцензії

PACSnumbers: 42.70.Jk, 62.23.Pq, 78.30.Jw, 81.07.Pr, 81.70.Pg, 82.35.Np, 82.56.Ub

\title{
Obtaining of Nanocomposites Based on Comb-Type Siloxane and Reduced Graphene Oxide
}

\author{
N. Jalagonia ${ }^{1}$, A. Hrubiak ${ }^{2}$, T. Kuchukhidze ${ }^{1}$, L. Kalatozishvili ${ }^{1}$, \\ E. Sanaia ${ }^{1}$, G. Bokuchava ${ }^{1}$, I. Petrova-Doycheva ${ }^{3}$, and V. Moklyak ${ }^{2}$ \\ ${ }^{1}$ LEPL Ilia Vekua Sukhumi Institute of Physics and Technology, \\ 7, Mindeli Str., \\ 0186 Tbilisi, Georgia \\ ${ }^{2}$ G. V. Kurdyumov Institute for Metal Physics, N.A.S. of Ukraine, \\ 36 Acad. Vernadsky Blvd., \\ UA-03142 Kyiv, Ukraine \\ ${ }^{3}$ Open Laboratory on Experimental Micro and Nano Mechanics, \\ Institute of Mechanics, Bulgarian Academy of Sciences, \\ Acad. G. Bonchev Str., Block 4, \\ 1113 Sofia, Bulgaria
}

Comb-type siloxane belongs to graft polymers with high density in segments of main backbone, which have considerable attracted interest of researchers due to unique architecture. Hydrosilylation reactions are used for synthesis of graft polymers. The aim of presented work is obtaining of photopolymers based on polydimethylsiloxane (PDMS). For this purpose, we have conducted hydrosilylation reaction of polymethylhydrosiloxane (PMHS) with allyl acrylate and vinyltriethoxysilane in the presence of Karstedt's catalyst in toluene. Nanocomposites are fabricated based on PDMS and reduced graphene oxide with different content in the range of 0.5-0.8 wt. \%. Materials' structure and composition are characterized by FTIR, NMR, TGA, DMTA, Raman, and SEM analyses in order to determine the structure, morphology, filler dispersion, defects and other characteristics.

Силоксан гребінчастого типу належить до прищеплених полімерів 3 високою щільністю у сегментах основного кістякового ланцюга, які викликали значний інтерес дослідників завдяки унікальній архітектурі. Реакції гідросилілування використовуються для синтези прищеплених полімерів. Метою представленої роботи є одержання фотополімерів на основі полідиметилсилоксану (ПДМС). Для цього нами було проведено реакцію гідросилілування поліметилгідросилоксану (ПМГС) з алілакрилатом і вінілтриетоксисиланом у присутності Карстедтового ката- 
лізатора в толуолі. Нанокомпозити виготовляються на основі ПДМС і відновленого оксиду графена 3 різним вмістом у діяпазоні 0,5-0,8 мас.\%. Структура та склад матеріялів характеризуються методами ФПІЧ, ЯМР, ТІА, ДМТА, Раманової аналізи та СЕМ з метою визначення структури, морфології, дисперсії наповнювача, дефектів та інших характеристик.

Силоксан гребенчатого типа относится к привитым полимерам с высокой плотностью в сегментах основной остовной цепи, которые вызвали значительный интерес исследователей благодаря уникальной архитектуре. Реакции гидросилилирования используются для синтеза привитых полимеров. Целью представленной работы является получение фотополимеров на основе полидиметилсилоксана (ПДМС). Для этого нами была проведена реакция гидросилилирования полиметилгидросилоксана (ПМГС) с аллилакрилатом и винилтриэтоксисиланом в присутствии катализатора Карстедта в толуоле. Нанокомпозиты изготавливаются на основе ПДМС и восстановленного оксида графена с различным содержанием в диапазоне 0,5-0,8 масс.\%. Структура и состав материалов характеризуются методами ФПИК, ЯМР, ТГА, ДМТА, рамановского анализа и СЭМ с целью определения структуры, морфологии, дисперсии наполнителя, дефектов и других характеристик.

Key words: comb-type siloxane, hydrosilylation, nanocomposite, $3 D$ printer.

Ключові слова: силоксан гребінчастого типу, гідросилілування, нанокомпозит, $3 D$-принтер.

Ключевые слова: силоксан гребенчатого типа, гидросилилирование, нанокомпозит, $3 D$-принтер.

(Received 21 June, 2019)

\section{INTRODUCTION}

Organo-siloxane polymers belong to hybrid materials, where organic groups are grafted on main inorganic siloxane backbone, and they are composed of organic groups hanging on the main inorganic silicon backbone. They also belong to semi-inorganic polymers' class. Interest towards organo-siloxane increases because of unique properties such as low glass-transition temperature, temperature and oxidative stability, low surface temperature, stability to UV irritation, hydrophobicity. It is possible to create new polymers by grafting various functional groups (epoxy, amine, carboxyl, anhydride, nitro, hydroxyl, vinyl, acryl and others) on main and side backbones [1-3].

Comb-type siloxane belongs to graft polymers with high density 
in segments of main backbone, which have considerable attracted interest of researchers due to a unique architecture [4-7].

Hydrosilylation reactions are characterized by great practical significance. They are the most effective and convenient methods for obtaining of relevant silicon-organic compounds. Silylation is used to obtain low-molecular compounds as well as molecular compounds and their modification. Great interest is due to the simplicity, convenience and absence of co-product [5,6].

Recently, hard and elastic materials with low density are used, and great attention is paid to composites based on polymers and carbon nanostructures (graphene, carbon nanotubes), owing to their unique electrical and mechanical properties [8-10].

Addition of carbon nanostructures into polymer materials gives very new properties of the obtained composite. For example, less than $1 \%$ carbon nanostructures in polymer increases electroconductivity by 10 times, thermal conductivity by $2-3$ times, etc.

\section{MATERIALS AND METHODS}

Materials. Polymethylhydrosiloxane (PMHS), allyl metacrylate, vinyltriethoxysilane, platinum (0)-1,3-divinyl-1,1,3,3-tetramethyl disiloxane complex (2\%-solution in xylene), diphenyl $(2,4,6$ trimethylbenzoyl) phosphine oxide supplied from Sigma Aldrich. Toluene was dried over and distilled from sodium under an atmosphere of dry nitrogen.

FTIR spectra were obtained on a Nicolet Nexus (Thermo Nicolet Corp., Madison, WI) 470 machine with a mercury-cadmiumtelluride detector type B (MCTB). ${ }^{1} \mathrm{H}-\mathrm{NMR}$ spectra were recorded on a Bruker (Rheinstetter, Germany) ARX400 NMR spectrometer at a $400 \mathrm{MHz}$ operating frequency with $\mathrm{CDCl}_{3}$ as the solvent and an internal standard.

Dynamic mechanical thermal analysis (DMTA) was also carried in temperature range from $-80^{\circ} \mathrm{C}$ to $20^{\circ} \mathrm{C}$; regime of oscillation was as follows: load $=1 \mathrm{~N}$, frequency $=1 \mathrm{~Hz}$.

Hydrosilylation Reaction of PMHS to Allylmetacrylate and Vinyltriethoxysilane. $1 \mathrm{~g}$ polymethylhydrosiloxane, $1.26 \mathrm{~g}$ allylmetacrylate, and $0.95 \mathrm{~g}$ vinyltriethoxysilane were placed into a $50 \mathrm{ml}$ flask under nitrogen. Then the mixture was dissolved $15 \mathrm{ml}$ of toluene, and $3 \mu \mathrm{L}$ Karstedt's catalyst was syringed into the flask. The homogeneous mixture was degassed and placed into an oil bath, which was previously set to $60^{\circ} \mathrm{C}$, and reaction continued at $70^{\circ} \mathrm{C}$. The reaction was controlled by decrease of intensity of active $\equiv \mathrm{Si}-\mathrm{H}$ groups (Scheme 1). Then $0.1 \%$ activated carbon was added and refluxed for $3 \mathrm{~h}$ for deactivation of catalysts. All volatiles were removed by rotary evaporation, and the obtained product was precipi- 


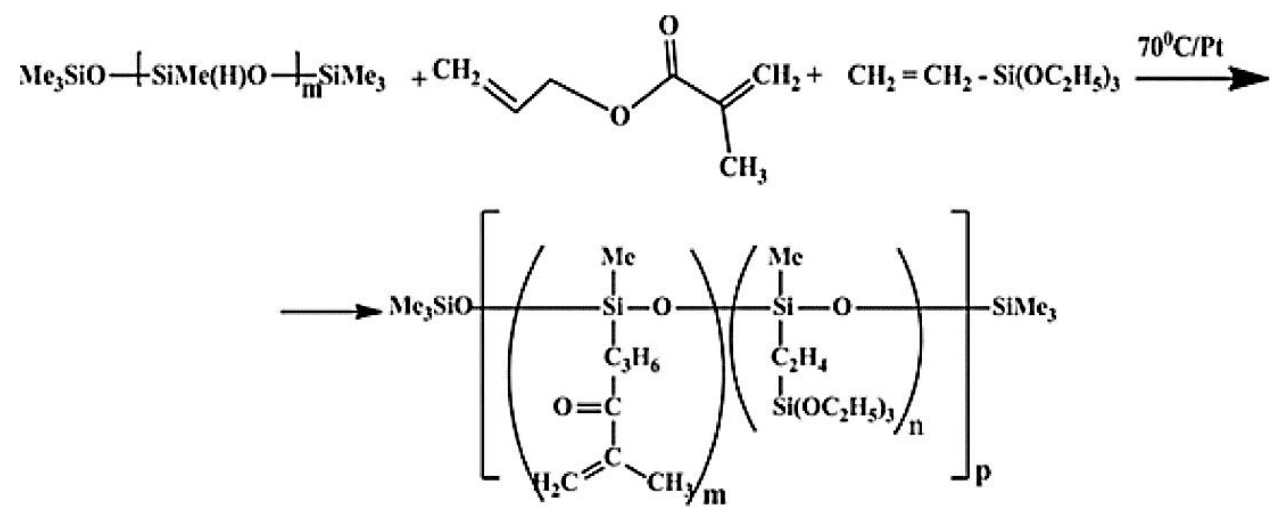

Scheme 1.

tated at least three times into pentane to remove side products. Finally, all volatiles were removed under vacuum, and colourless viscous product was obtained.

Synthesis of Reduced Graphene Oxide (rGO). Synthesis of graphene oxide was carried out by modified Hummers method. $300 \mathrm{ml}$ flask was placed into an ice bath, $3 \mathrm{~g}$ natural graphite was added into a mixture of $30 \mathrm{ml} 98 \% \mathrm{H}_{2} \mathrm{SO}_{4}, 2.5 \mathrm{~g} \mathrm{~K}_{2} \mathrm{~S}_{2} \mathrm{O}_{8}$ and $2.5 \mathrm{~g} \mathrm{P}_{2} \mathrm{O}_{5}$, and the solution was stirred at $80^{\circ} \mathrm{C}$ during $5 \mathrm{~h}$. Pre-oxidized graphite was washed and dried in vacuum. Obtained product was mixed with 100 $\mathrm{ml} 98 \% \mathrm{H}_{2} \mathrm{SO}_{4}$, and $7.5 \mathrm{~g} \mathrm{KMnO}_{4}$ was added at a temperature bellow $15^{\circ} \mathrm{C} ; 150 \mathrm{ml} \mathrm{H}_{2} \mathrm{O}$ was added and stirred during $2 \mathrm{~h}$; additional 200 $\mathrm{ml} \mathrm{H}_{2} \mathrm{O}$ and $15 \mathrm{ml} 30 \% \mathrm{H}_{2} \mathrm{O}_{2}$ dropwise were added into a solution. Resulting mixture was washed, and product was obtained after drying in a vacuum oven. Ethanol was added in the obtained product, and sonication was carried out during $30 \mathrm{~min}$ to obtain stable suspension. Reduction of GO solution was carried out in microwave.

\section{RESULTS AND DISCUSSION}

The aim of presented work was obtaining of photopolymers based on PDMS [11-13]. For this purpose, we have conducted hydrosilylation reaction of polymethylhydrosiloxane (PMHS) with allyl acrylate and vinyltriethoxysilane in the presence of Karstedt's catalyst in toluene. Obtained polymer is liquid and well soluble in organic solvents with specific viscosity $\eta_{\mathrm{sp}} \approx 0.4$. The end of reaction was tested by FTIR, where peak at $1260 \mathrm{~cm}^{-1}$ belonging to $\mathrm{Si}-\mathrm{H}$ bonds disappears. After this, the polymer was distilled in vacuum; cross-linking agent was add about $1 \%$ and cured by UV during $1 \mathrm{~h}$.

Second step was the addition of photoinitiator, which is dissolved 
in monomer and reduced graphene oxide. Nanocomposite was obtained by solution-mixing method. Then, polymer surface was treated by Ar and curing by UV for 2-3 h.

The structure and composition of the obtained compounds were studied by determination of molecular masses, FTIR, ${ }^{1} \mathrm{H}-\mathrm{NMR}$ spectra data, SEM, TGA, and DMTA.

In the FTIR spectra (Fig. 1, $a$ ), we observed absorption bands characteristic for $\equiv \mathrm{Si}-\mathrm{CH}_{3}-\mathrm{Si} \equiv$ bonds at $1044 \mathrm{~cm}^{-1}$ and absorption bands characteristic for $-\mathrm{CH}_{2}-$ at $2860 \mathrm{~cm}^{-1}$. Results showed that all active $\mathrm{Si}-\mathrm{H}$ bonds of $\mathrm{PMHS}$ enter in hydrosilylation reaction with allyl methacrylate and vinyltriethoxysilane. In the ${ }^{1} \mathrm{H}-\mathrm{NMR}$ spectra (Fig. 1,b), we observed signals characteristic for methyl protons of $\equiv \mathrm{Si}-\mathrm{CH}_{3}$ and $\equiv \mathrm{Si}-\left(\mathrm{CH}_{3}\right)_{3}$ with chemical shifts $\delta \approx 0.09$ ppm. Triplet signal with centre of chemical shift at $\delta \approx 2.30 \mathrm{ppm}$ and $\delta \approx 2.50 \mathrm{ppm}$ corresponds to protons' methylene-groups' fragment.

Synthesized GO was characterized by Raman spectroscopy and SEM (Fig. 2, $a, b$ ). In the Raman spectrum, the G-band and D-band of GO appear at $1595 \mathrm{~cm}^{-1}$ and $1347 \mathrm{~cm}^{-1}$, respectively. SEM shows that obtained $r$ GO layers have thickness $\approx 20-40 \mathrm{~nm}$.

Mechanical properties of obtained polymers depend on intensity of UV irritation. These eco-friendly photopolymers can be used successfully in SLA $3 D$ printer.

$r \mathrm{GO} /$ polymer nanocomposites were prepared by physical mixing method. At first, filler mixed into liquid polymer, which is dissolved in organic solvent. Then, solvent is removed by evaporation, and composite is obtained, where filler is distributed well in polymer. Results show that addition of carbon nanostructures in polymers improves number of composite properties.

Dynamic mechanical measurements are very sensitive to the

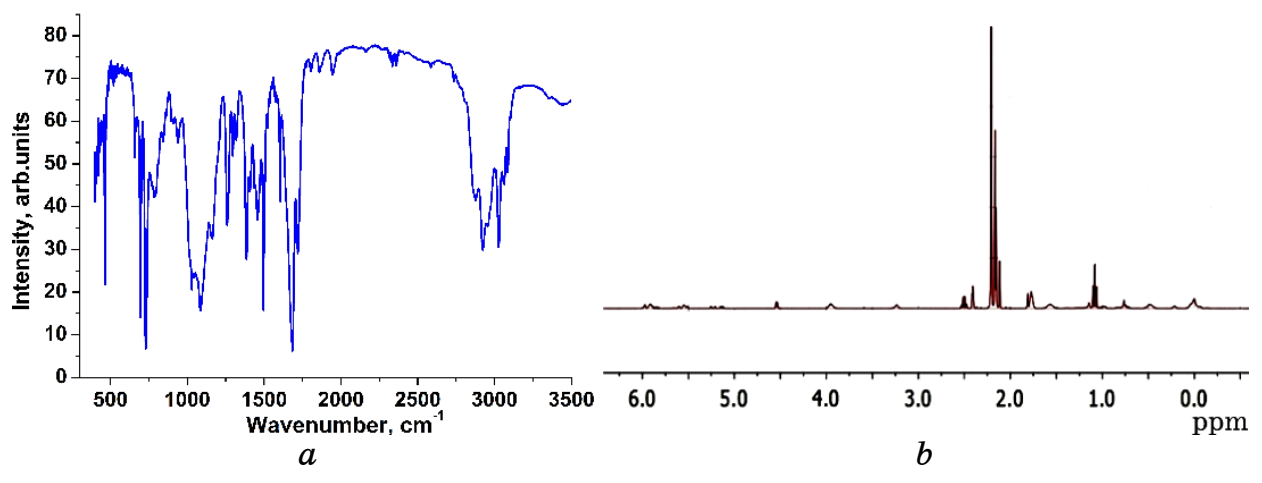

Fig. 1. FTIR data $(a)$ and ${ }^{1} \mathrm{H}$ NMR $(b)$ of UV curable PDMS. 


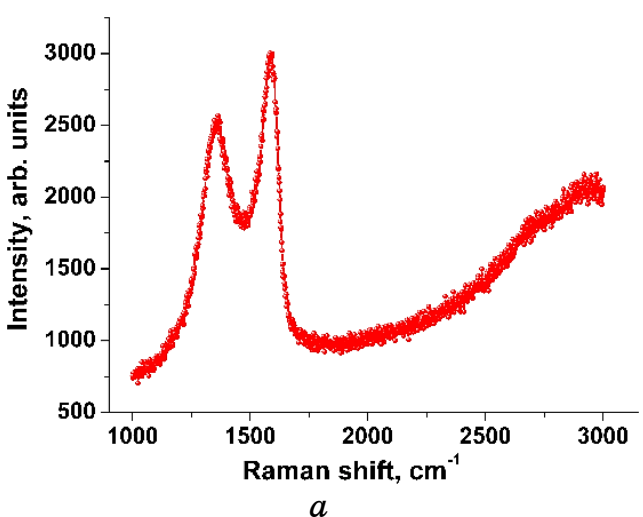

$a$

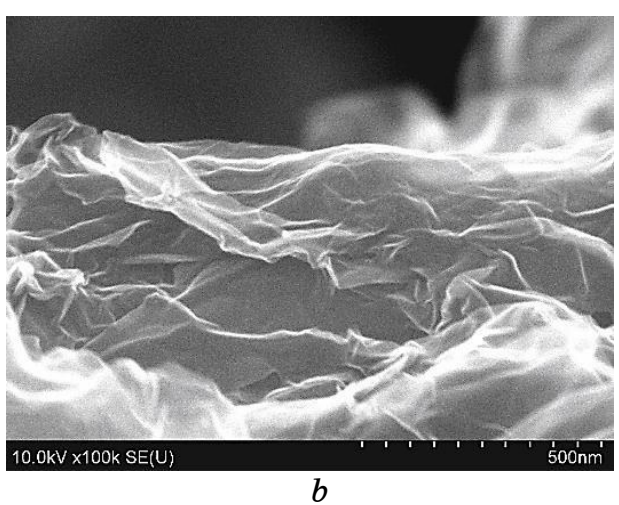

$b$

Fig. 2. Raman spectrum (a) and SEM (b) of reduced graphene oxide.

chemical and physical structures of polymeric materials. In this work, DMTA was used to verify the composite morphology and to measure its glass-transition temperatures (Fig. 3, a). The results were obtained with a frequency of $1 \mathrm{~Hz}$.

In the DMTA data, the low-temperature zone corresponds to the glassy state of the polymer, where the storage modulus is high and decreases slowly with the increase of the temperature. Storage modulus increases as the concentration of $r \mathrm{GO}$ rises (Fig. 3, b). According to TGA data, $r$ GO/siloxane nanocomposite starts slow losing mass between $250-400^{\circ} \mathrm{C}$ due to polymer degradation, and the rest of the carbon material remains stable up to $\approx 700^{\circ} \mathrm{C}$.
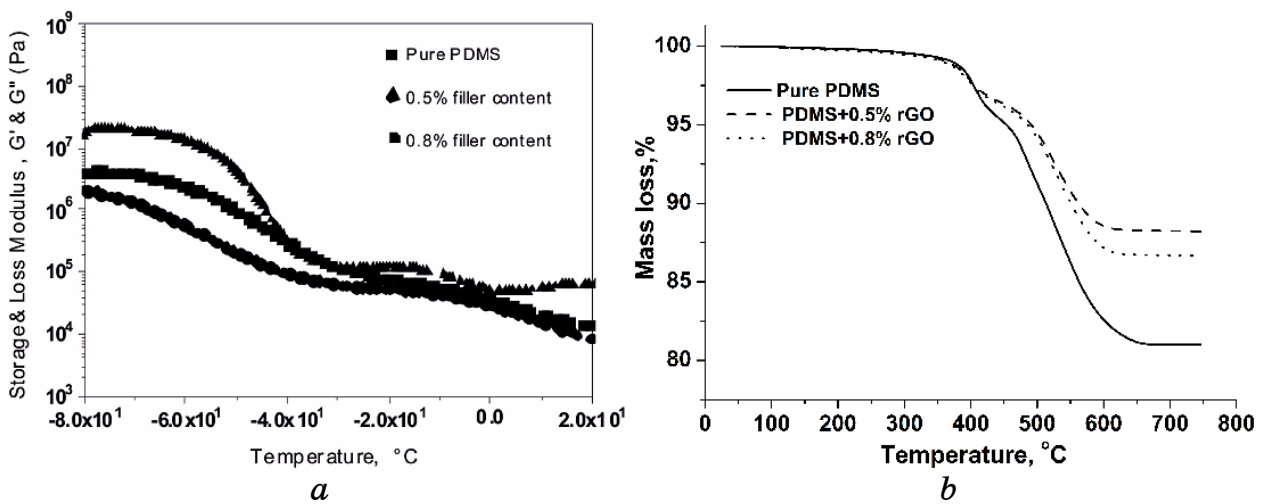

Fig. 3. Storage modulus and loss modulus as functions of temperature $(a)$ and TGA $(b)$ of nanocomposite. 


\section{CONCLUSIONS}

The UV-curable PDMS samples were successfully synthesized by hydrosilylation reaction in the presence of Karstedt's catalyst. The optimal reaction condition for completely converting - $\mathrm{SiH}$ groups to methacrylate and vinyl groups were used with a ratio of 1:20:30. The synthesized polymers were investigated by FTIR, ${ }^{1} \mathrm{H}$ NMR, TGA, and DMTA. Results showed that all active $\mathrm{Si}-\mathrm{H}$ bonds of PMHS enter in hydrosilylation reaction with allyl methacrylate and vinyltriethoxysilane. Mechanical properties of the obtained polymers depend on intensity of UV irritation. These photopolymers can be successfully used in SLA $3 D$ printer. Nanocomposites were prepared by physical mixing method.

\section{ACKNOWLEDGMENTS}

This work has been supported by the H2020 MCA RISE project 'Graphene-3D', Grant No. 734164, funded by the European Union.

\section{REFERENCES}

1. J. E. Mark, Macromolecules, 11, No. 4: 627 (1978); https://doi.org/10.1021/ma60064a001.

2. I. Yilgor and J. E. McGrath, Polysiloxane Copolymers/Anionic Polymerization. In: Advances in Polymer Science (Berlin-Heidelberg: Springer-Verlag: 1988).

3. C. Eaborn, Organische Verbindingen. In: Organosilicon Compounds (London: Butterworth Scientific Publications: 1960).

4. E. G. Rochow and W. F. Gilliam, J. Am. Chem. Soc., 67, No. 6: 1772 (1945).

5. R. G. Jones, W. Ando, and J. Chojnowski, Silicon-Containing Polymers. In: The Science and Technology of Their Synthesis and Applications (Dordrecht: KluwerAcademic Publishers: 2000).

6. B. Thavornyutikarn, R. Nonthabenjawan, P. Ngamdee, and W. Janvikul, Journal of Metals, Materials and Minerals, 18, No. 2: 213 (2008).

7. Y. Karatas, N. Kaskhedikar, M. Burjanadze, and H.-D. Wiemhöfer, Macromol. Chem. Phys, 207, No. 4: 419 (2006); https://doi.org/10.1002/macp.200500470.

8. S. Stankovich, D. A. Dikin, R. D. Piner, K.A. Kohlhaas, A. Kleinhammes, Y. Jia, Y. Wu, S.T. Nguyen, and R. S. Ruoff, Carbon, 45, No. 2: 1558 (2007); https://doi.org/10.1016/j.carbon.2007.02.034.

9. J. Du and H. M. Cheng, Macromolecular Chemistry and Physics, 213, Nos. 10-11: 1060 (2012); https://doi.org/10.1002/macp.201200029.

10. S. X. Zhou, Y. Zhu, H. D. Du, B. H. Li, and F. Y. Kang, New Carbon Mater., 27, No. 4: 241 (2012); https://doi.org/10.1016/S1872-5805(12)60015-8.

11. N. Jalagonia, I. Esartia, T. Tatrishvili, E. Markarashvili, J. Aneli, and O. Mukbaniani, Oxid. Commun., 39, No. 2: 1282 (2016).

12. O. Mukbaniani, J. Aneli, I. Esartia, T. Tatrishvili, E. Markarashvili, and 
N. Jalagonia, Macromolecular Symposia, 328, No. 1: 25 (2013); https://doi.org/10.1002/masy.201350603.

13. N. Jalagonia, T. Kuchukhidze, E. Sanaia, L. Kalatozishvili, R. Ivanova, B. Khvitia, and G. Bokuchava, Bulletin of the Georgian National Academy of Science, 12, No. 4: 72 (2018). 